Check for updates

Cite this: RSC Adv., 2021, 11, 19587

Received 31st March 2021

Accepted 24th May 2021

DOI: $10.1039 / d 1 r a 02553 h$

rsc.li/rsc-advances

\section{First total synthesis of chromanone A, preparation of related compounds and evaluation of their antifungal activity against Candida albicans, a biofilm forming agent $\uparrow$}

\begin{abstract}
Iván Cortés, (DD a Estefanía Cordisco, (D) ${ }^{b}$ Teodoro S. Kaufman, (D) *a Maximiliano A. Sortino, (D) ${ }^{b}$ Laura A. Svetaz (D) *b and Andrea B. J. Bracca (D) *a

A straightforward and convenient approach for the first total syntheses of chromanone A and a related 7OMe substituted natural product is reported. These unique C-3 substituted 2-hydroxymethyl chromones were recently isolated as fungal metabolites. Chromanone A was synthesized in $25.3 \%$ overall yield from the readily available pyrocatechol, whereas the second natural product was prepared in $39.7 \%$ global yield. A small library of chromones, including both natural products and some of their synthetic heterocyclic precursors, was evaluated against Candida albicans ATCC 10231, a biofilm forming agent. It was found that 8-methoxy-3-methyl-4-oxo-4H-chromene-2-carbaldehyde, a partially oxidized form of chromanone A, exhibited a minimum inhibitory concentration of $7.8 \mu \mathrm{g} \mathrm{mL}^{-1}$ and significantly inhibited the yeast's virulence factors, including the adherence to buccal epithelial cells and the secretion of phospholipases, as well as the formation of germ tubes and the generation of the hyphal pseudomycelium. In addition, despite the heterocycle exhibiting non-significant inhibition of the formation of the Candida biofilm, it completely inhibited the growth of $C$. albicans in preformed biofilms at $62.5 \mu \mathrm{g} \mathrm{mL}^{-1}$.
\end{abstract}

\section{Introduction}

Biofilms are structured microbial communities, embedded in a self-produced polymeric matrix of protein and polysaccharides. They are frequently found on interfaces or attached to surfaces, and are the scenario of complex interactions. These enduring structures are elusive to the defense system of the host, reluctant to undergo phagocytosis, and offer the producing microorganism a markedly increased resistance to antibiotics and chemical disinfectants. ${ }^{1 \boldsymbol{a}}$ Therefore, biofilms are an important form of microbial resistance and transmission of chronic infections. $^{\mathbf{1 b}}$

The biofilms are ubiquitous, and their presence on surfaces such as biomedical implants, may put at risk complex surgical interventions and ultimately compromise the life of the patient.

\footnotetext{
${ }^{a}$ Instituto de Química Rosario (IQUIR, CONICET-UNR), Facultad de Ciencias Bioquímicas y Farmacéuticas, Universidad Nacional de Rosario, Suipacha 531, S2002LRK Rosario, Argentina. E-mail: kaufman@iquir-conicet.gov.ar; bracca@ iquir-conicet.gov. ar

${ }^{b}$ Area Farmacognosia, Facultad de Ciencias Bioquimicas y Farmacéuticas, Universidad Nacional de Rosario, Suipacha 531,S2002LRK Rosario, Argentina.E-mail: lsvetaz@ fbioyf.unr.edu.ar

$\dagger$ Electronic supplementary information (ESI) available: NMR spectra of the intermediates and final products, bioactivity testing methodology and results of inhibition assays. See DOI: 10.1039/d1ra02553h
}

In this context, there is a need for antimicrobial agents capable of attacking microorganisms within the biofilms. Hence, the search for new compounds endowed with this property is currently relevant.

The chromone skeleton is a "privileged structure", ${ }^{2 a}$ meaning a promising motif for drug development. Not surprisingly, substituted chromones are known to display a variety of useful biological properties, including antifungal activity. ${ }^{2 b, c}$

In 2009, Gamal-Eldeen and coworkers reported the isolation of chromanone A (A, Fig. 1), ${ }^{3}$ from an algicolous marine Penicillium species, cultivated on a solid biomalt medium. In turn, this fungus was isolated as an endophyte of the Egyptian green alga Ulva sp. The natural product inhibits the activity of CYP1A at a level of $4 \mu \mathrm{g} \mathrm{mL} \mathrm{m}^{-1}$, being a potential cancer chemopreventive agent. $^{3}$

The structure of the natural product was assigned based on an analysis of 1D and 2D (HSQC, HMBC) NMR spectra. Being a member of the very small family of the naturally occurring 2hydroxymethylchromones which bear a C-3 functionalization, chromanone $\mathrm{A}$ is a structurally unique chromone. Its special structural characteristics are shared only by a handful of natural products, such as its isomer B, recently isolated from Rhinocladiella sp., a fungus obtained from the marine sponge Ircinia oros. $^{4 a}$ These features are also found in heterocycles $\mathbf{C}^{4 b}$ and $\mathbf{D},{ }^{4 c}$ 
<smiles>[R]c1cc([R])c2c(=O)c([R])c(CO)oc2c1[R]</smiles>

A $R=R^{1}=H, R^{2}=O M e, R^{3}=M e$ $B R=R^{2}=H, R^{1}=O M e, R^{3}=M e$ $C \mathrm{R}=\mathrm{OH}, \mathrm{R}^{1}=\mathrm{OMe}, \mathrm{R}^{2}=\mathrm{H}, \mathrm{R}^{3}=\mathrm{Me}$<smiles>COc1cc2oc(CO)c(-c3cccc(O)c3O[C@H]3O[C@H](CO)[C@@H](O)[C@H](O)[C@H]3O)c(=O)c2c(O)c1C</smiles>
$D R=R^{2}=H, R^{1}=O M e, R^{3}={ }^{\mathrm{B}} \mathrm{Bu}$

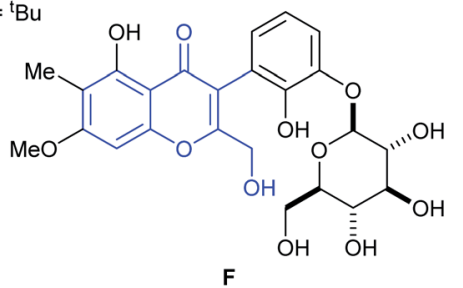

Fig. 1 Chromanone A (A) and related naturally occurring 3substituted-2-hydroxymethyl chromone derivatives.

as well as in boeravinone $\mathrm{Q}(\mathbf{E})^{5 a}$ and its congener mirabijalone $\mathrm{C}(\mathbf{F}){ }^{5 b}$

Our work is focused on the synthesis of structurally unique heterocyclic natural products, ${ }^{6}$ as well as in their evaluation. ${ }^{7 a, b}$ Further, among chromone derivatives, we have developed the total synthesis of the structure assigned to aspergillitine, ${ }^{7 c}$ a $2,3-$ dimethyl chromone derivative isolated from a marine Aspergillus species.

In pursuit of these interests, here we report an efficient approach to the first total syntheses of chromanone A (A) and of its isomer, the related natural product $\mathbf{B}$. The results of the evaluation of both natural products and their heterocyclic synthetic intermediates, as antifungal agents against the biofilm forming yeast Candida albicans ATCC 12031, are also discussed.

\section{Results and discussion}

\subsection{Chemistry}

The initial step toward chromanone A as the first target (1), was a retrosynthetic analysis of the product (Scheme 1). Initially, focus was made on the oxygen bearing functionality of the 2hydroxymethyl feature; a functional group interconversion was proposed, conjecturing that the proper oxidation stage of the C2 substituent could be set either through reduction (aldehyde, ester, 2a) or by means of a selective oxidation. ${ }^{7 a}$ The latter possibility revealed the 2,3 -dimethylchromone $\mathbf{2 b}$ as a suitable precursor.

Then, two different alternatives were considered. In one of them (Route a), the heterocyclic ring of $\mathbf{2 a} \mathbf{a}, \mathbf{b}$ was disassembled as shown, to unveil a propiophenone derivative (3), which was further submitted to a $\mathrm{C}-\mathrm{O}$ disconnection on the aliphatic side of the carbonyl moiety (bond $\alpha$ ), to uncover ortho-vanillin (5) as a suitable starting material.

In the second case (Route b), an additional methyl ether $\mathrm{C}-\mathrm{O}$ disconnection was considered on the chromone 2, which suggested the catechol derivative $\mathbf{4}$ as the most appropriate synthetic intermediate. In turn, a $\mathrm{C}-\mathrm{O}$ disconnection on the
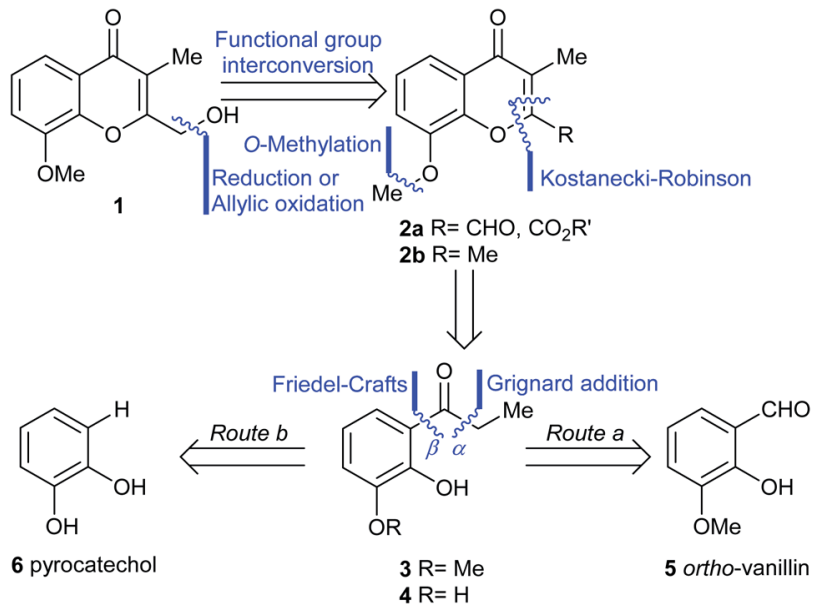

Scheme 1 Retrosynthetic analyses of chromanone A (1).

aromatic side of the carbonyl motif of propiophenone 4 (bond $\beta)$ set aside the three-carbon side chain and determined that the logical starting material for this approach was the commercially available pyrocatechol (6).

For simplicity, the Route a was explored first. Thus, orthovanillin (5) was subjected to a 1,2-addition to the carbonyl with excess ethyl Grignard reagent (Scheme 2), freshly prepared from iodoethane and activated magnesium. The reaction was executed at room temperature (RT), giving alcohol 7 in $97 \%$ yield. ${ }^{8}$

Subsequently, 7 was submitted to a selective oxidation of its secondary alcohol moiety. Different conditions [PDC, $\mathrm{CH}_{2} \mathrm{Cl}_{2}$; $\mathrm{H}_{2} \mathrm{~N}-\mathrm{NH}_{2} \cdot x \mathrm{H}_{2} \mathrm{O}, \mathrm{DMSO} / \mathrm{I}_{2}, \mathrm{MeCN} / \mathrm{H}_{2} \mathrm{O}(5: 1, \mathrm{v} / \mathrm{v}) ; \mathrm{DMSO} / \mathrm{Ac}_{2} \mathrm{O}$ (2.3 equiv.); IBX (1.5 equiv.), EtOAc $]^{9}$ were tested; however, the reaction proved most successful with IBX in EtOAc, furnishing ketone 3 in up to $81 \%$ yield in just one hour at room temperature. $^{10}$ Unfortunately, this transformation proved to lack robustness, being highly dependent on the experimental conditions, including the source of the oxidizing reagent. This characteristic frequently resulted in an exacerbated concomitant oxidation of the ortho-phenol, ultimately causing tarry materials and low yields.<smiles>CCC(=O)c1ccc(C)c(O)c1O</smiles><smiles>COc1cccc2c(=O)c(C)c(CO)oc12</smiles><smiles>CCOc1oc2c(OC)cccc2c(=O)c1C</smiles>

Scheme 2 Reagents and conditions (a) $\mathrm{CH}_{3} \mathrm{CH}_{2} \mathrm{l}, \mathrm{Mg}^{\circ}, \mathrm{Et}_{2} \mathrm{O}, \mathrm{RT}(97 \%$ ); (b) IBX, EtOAc, RT, 1 h (81\%); (c) $\mathrm{EtO}_{2} \mathrm{C}-\mathrm{COCl}_{2} \mathrm{Et}_{3} \mathrm{~N}, \mathrm{CH}_{2} \mathrm{Cl}_{2}, \mathrm{MW}(100$ $\left.{ }^{\circ} \mathrm{C}\right), 1$ h (42\%); (d) $\mathrm{NaBH}_{4}, \mathrm{CaCl}_{2}, \mathrm{EtOH}, 0{ }^{\circ} \mathrm{C}, 24 \mathrm{~h}(41 \%)$. 
Next, a one-pot Kostanecki-Robinson cyclization protocol was practiced on the propiophenone 3 in order build the chromone system. The reaction of aromatic ketones with a glycolate ether was considered as an alternative, to access a 2alkoxymethylene chromone; however, it generally proved to proceed in low yield ${ }^{11 a}$ and was soon discarded due to inability of the product to withstand the harsh conditions required to break the ether bond and the lack of selectivity of the reaction. In addition, model experiments with the scarcely precedented use of glyoxal ${ }^{11 b}$ as a two-carbon synthon, which would have delivered a 2-hydroxymethyl chromone directly, met with failure; no reaction was observed, despite different basic conditions (KOH, ${ }^{t} \mathrm{BuO}$ and $\mathrm{NH}_{4} \mathrm{OH}$ in EtOH) were explored.

Therefore, the ketone $\mathbf{3}$ was exposed to ethyl chlorooxoacetate ${ }^{12}$ which can be regarded as an oxidized form of glyoxal or glycolate ethers. Luckily, the reaction took place in $\mathrm{CH}_{2} \mathrm{Cl}_{2}$, in the presence of triethylamine at $100{ }^{\circ} \mathrm{C}$ under microwaves irradiation (MW), giving chromone 8 in a reproducible but rather moderate $(42 \%)$ yield.

Finally, the required adjustment of the oxidation state of the C-2 substituent was carried out by means of a selective reduction of 8; however, since the use of $\mathrm{NaBH}_{4}$ as reducing agent ${ }^{13}$ did not perform as expected, this challenging transformation was carried out with $\mathrm{Ca}\left(\mathrm{BH}_{4}\right)_{2} \cdot{ }^{14}$ The reagent was prepared in situ by adding a stoichiometric amount of $\mathrm{CaCl}_{2}$ to $\mathrm{NaBH}_{4}$ in EtOH. ${ }^{14 c}$ Under these conditions, chromanone A (1, compound A of Fig. 1) was obtained in $41 \%$ yield. Its spectroscopic data in $\mathrm{CDCl}_{3}$ confirmed its structure, whereas the NMR spectra taken in $\mathrm{MeOH}-d_{4}$ were in full agreement with those reported for the natural product. ${ }^{3}$ Signal enhancement (NOE) of the $\mathrm{CH}_{2} \mathrm{OH}$ moiety $(0.8 \%)$ was observed upon irradiation of the hydrogen atoms of the 3-Me group, as well as between the hydrogen atoms of the 8-OMe group and $\mathrm{H}-7$ (1.7\%). Notably, the spectra taken in both solvents were alike, and differences exceeding $10 \mathrm{ppm}$ were found between them, particularly for the carbon atoms of the isocyclic ring attached to oxygen.
Despite this first approach to 1 afforded the natural product in just four steps and $13.5 \%$ overall yield, the lack of robustness of the selective oxidation of 7 , coupled to the moderate yields of the cyclization toward $\mathbf{8}$ and its selective ester moiety reduction stages, suggested the need to devise an improved alternative.

Therefore, we resorted to the second synthetic plan toward $\mathbf{1}$, commencing with the selective Friedel-Crafts ortho-acylation of pyrocatechol (6) under $\mathrm{BF}_{3} \cdot \mathrm{OEt}_{2}$ promotion. ${ }^{15}$ However, since in our hands the reported procedure proved hard to be reproduced, a series of optimization experiments were run in order to find the proper reaction conditions.

In the process, it was soon found that $\mathrm{ZnCl}_{2}$ and $\mathrm{AlCl}_{3}$ are not suitable promoters, and that the use of 1,2-dichlorobenzene as solvent negatively affects the reaction performance. It was also discovered that under conventional thermal conditions (Table 1), the transformation hardly proceeded after 3 days at $110{ }^{\circ} \mathrm{C}$ (entry 1), whereas only small amounts of product were recovered when the reaction was performed at $180^{\circ} \mathrm{C}$ for $5 \mathrm{~h}$ (entry 2).

On the other hand, employing microwaves radiation, no product was isolated after $10 \mathrm{~min}$ at $180^{\circ} \mathrm{C}$ (entry 3), whereas slightly milder conditions $\left(170{ }^{\circ} \mathrm{C}, 5 \mathrm{~min}\right)$ resulted in $33 \%$ yield of product (entry 4), when 10 equiv. $\mathrm{EtCO}_{2} \mathrm{H}$ were used. Increasing the amount of acid caused a further increase in the yield to $61 \%$ (entry 5), while unexpectedly, additional amounts of acid produced a drastic yield reduction (entry 6). In addition, performing the reaction at $160{ }^{\circ} \mathrm{C}$ for $10 \mathrm{~min}$ (entry 7) or in the presence of propionic anhydride (entry 8 ) did not improve the results.

Therefore, the reaction was best performed as in entry 5 , in a solventless condition and under microwaves irradiation, affording consistently over $60 \%$ yield of the expected product $4 .{ }^{16}$ The use of 6 instead of guaiacol for this approach was based on literature precedents, which suggested that the latter should not be a suitable starting material because it would afford the unwanted propiophenone isomer. ${ }^{17 a, b}$

Next, 4 was cyclocondensed and further cyclized with $\mathrm{Ac}_{2} \mathrm{O}$ under Kostanecki-Robinson conditions, uneventfully affording

Table 1 Optimization of the synthesis of propiophenone 4

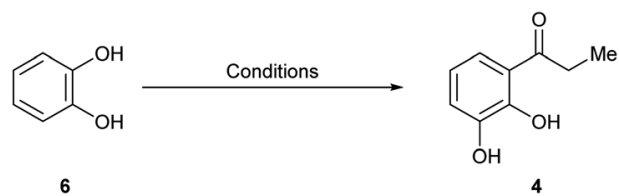

\begin{tabular}{|c|c|c|c|c|c|c|}
\hline Entry no. & $\mathrm{EtCO}_{2} \mathrm{H}$ (equiv.) & $\mathrm{BF}_{3} \cdot \mathrm{Et}_{2} \mathrm{O}$ (equiv.) & Temp. $\left({ }^{\circ} \mathrm{C}\right)$ & Power MW (W) & Time (min) & Yield of $4(\%)$ \\
\hline 1 & 9 & 1 & 110 & - & 3 days & 7 \\
\hline 2 & 13 & 1 & 180 & - & 300 & 23 \\
\hline 4 & 10 & 1.5 & 170 & 100 & 5 & 33 \\
\hline 5 & 12 & 1 & 170 & 100 & 5 & 61 \\
\hline 6 & 20 & 1 & 170 & 100 & 5 & 27 \\
\hline
\end{tabular}

${ }^{a}$ Propionic anhydride was employed, in the presence of BHT (0.05 equiv.). 
the expected 2,3-dimethylchromone 9 (ref. 7c) in 76\% yield (Scheme 3). A subsequent Williamson $O$-methylation of 9 with $\mathrm{MeI} / \mathrm{K}_{2} \mathrm{CO}_{3}$ in refluxing acetone gave $94 \%$ yield of $2 .{ }^{17 c}$ This was followed by a selective oxidation with the versatile $\mathrm{I}_{2} / \mathrm{DMSO}$ reagent system, which conveniently furnished aldehyde $\mathbf{1 0}$ in $83 \%$ yield. The transformation, which was carried out aerobically, required the addition of $\mathrm{TsOH}^{18 a}$

Finally, the reduction of the formyl moiety with $\mathrm{NaBH}_{4}$ in EtOH uneventfully provided the expected product 1 in $70 \%$ yield. Interestingly, unlike the reduction of compound $\mathbf{8}$, in this case the use of $\mathrm{Ca}\left(\mathrm{BH}_{4}\right)_{2}$ proved to be unnecessary, since the formyl group attached to $\mathrm{C}-2$ is much more reactive than the $\mathrm{C}-4$ ketone moiety.

This optimized approach gave 1 in $25.3 \%$ overall yield, after five synthetic steps. The NMR spectroscopic data of the synthetic compound (in $\mathrm{MeOH}-d_{4}$ ) were in excellent agreement with those of the literature, ${ }^{3}$ and the heterocycle obtained through Route a, confirming the structure of the natural product.

The intimate details of the mechanism of the key $\mathrm{I}_{2} / \mathrm{DMSO}-$ mediated oxidation toward 10 remain unclear; however, based on some previous literature precedents, a polar rather than a free-radical reaction mechanism can be proposed. Further, considering that the 2-methylchromone moiety may be regarded as a vinylogous $\alpha$-methylketone, ${ }^{18}$ it can be conjectured that a Kornblum-like oxidation is at the heart of the mechanistic sequence (Scheme 4). In this scenario, at first the carbonyl group of the substrate (2) would be activated by the added $\mathrm{TsOH}$, giving rise to intermediate I. In turn, this intermediate would be subjected to deprotonation to provide the dienol II, being followed by an iodination with $\mathrm{I}_{2}$, to generate the reactive iodide III.

Next, in the presence of DMSO which plays the dual role of solvent and oxidant, the iodide III would undergo a $\mathrm{SN}_{2}$-type reaction with the nucleophilic oxygen atom of the reagent, losing iodide and forming the alkoxysulfonium salt

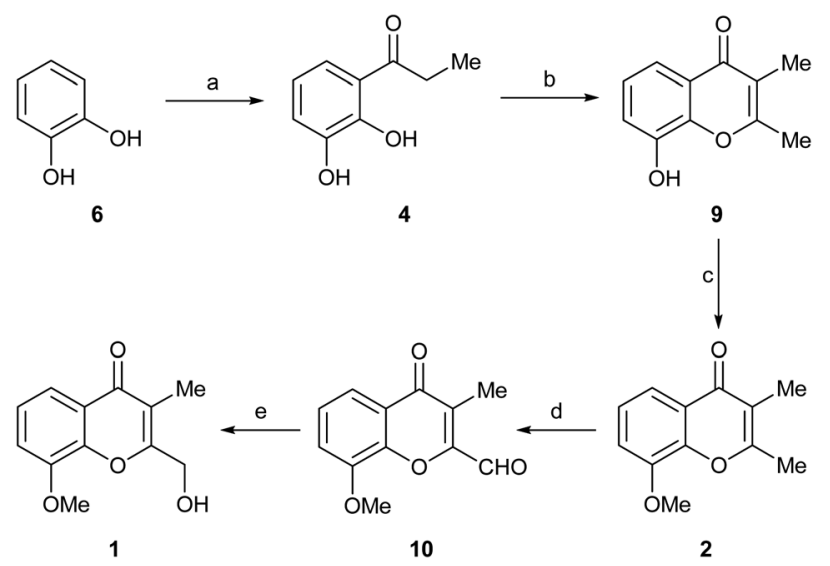

Scheme 3 Reagents and conditions: (a) $\mathrm{MeCH}_{2} \mathrm{CO}_{2} \mathrm{H}, \mathrm{BF}_{3} \cdot \mathrm{OEt}_{2}, \mathrm{MW}$ $\left(160{ }^{\circ} \mathrm{C}\right), 5 \mathrm{~min}(61 \%) ;\left(\right.$ b) $1 . \mathrm{Ac}_{2} \mathrm{O}, \mathrm{NaOAc}$, reflux, $3 \mathrm{~h} ; 2 . \mathrm{Et}_{3} \mathrm{~N}, 115^{\circ} \mathrm{C}$, $14 \mathrm{~h} ; 3.1 \mathrm{M} \mathrm{HCl}, 40{ }^{\circ} \mathrm{C}, 3 \mathrm{~h}$ (76\% overall); (c) $\mathrm{K}_{2} \mathrm{CO}_{3}, \mathrm{Mel}, \mathrm{Me}_{2} \mathrm{CO}$, reflux, $24 \mathrm{~h}(94 \%) ;(d) \mathrm{I}_{2}, \mathrm{TsOH}, \mathrm{DMSO}, \mathrm{O}_{2}, 130{ }^{\circ} \mathrm{C}, 2 \mathrm{~h}(83 \%)$; (e) $\mathrm{NaBH}_{4}, \mathrm{EtOH}$, $\mathrm{O}^{\circ} \mathrm{C} \rightarrow \mathrm{RT}, 1 \mathrm{~h}(70 \%)$.

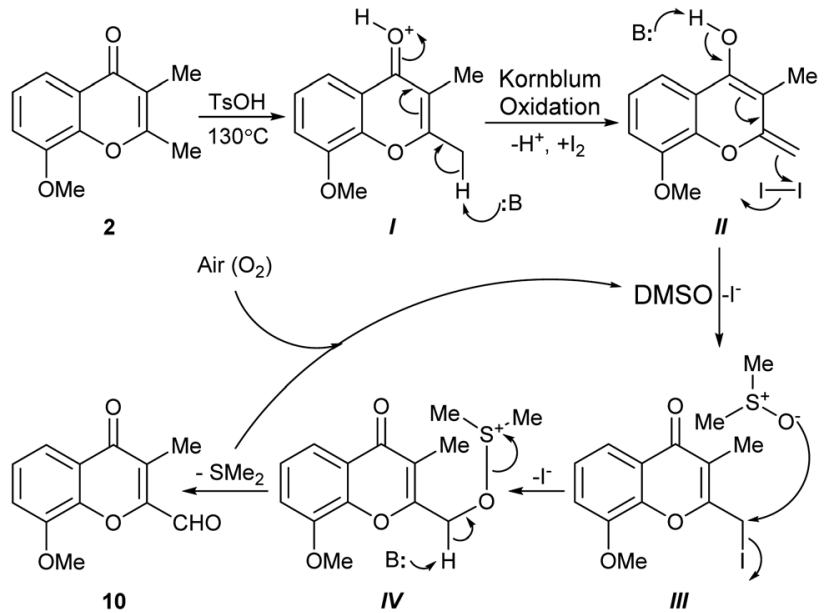

Scheme 4 The Kornblum oxidation-based mechanistic proposal for the conversion of 2,3-dimethylchromone 2 into 10 with the $I_{2} / D M S O$ reagent system.

intermediate IV. The latter would undergo a proton abstraction, resulting in the aldehyde product $\mathbf{1 0}$. Interestingly, it has been reported that reaction of a primary iodide like III with $\mathrm{KO}_{2}$ in DMSO afforded a hydroxymethyl chromone, albeit in rather low yield $(27 \%){ }^{19}$

During the reaction two molecules of $\mathrm{HI}$ and one of $\mathrm{SMe}_{2}$ are produced. Although DMSO can oxidize iodide ions to iodine, generating $\mathrm{SMe}_{2}\left(\mathrm{DMSO}+2 \mathrm{I}^{-} \rightarrow \mathrm{SMe}_{2}+\mathrm{I}_{2}+\mathrm{H}_{2} \mathrm{O}\right)$, it is assumed that the presence of oxygen (air) under the strenuous reaction conditions $\left(130^{\circ} \mathrm{C}\right)$ would serve to reoxidize all the $\mathrm{SMe}_{2}$ formed in the transformation and/or to regenerate the iodine in the presence of DMSO.

The general guidelines provided by the retrosynthetic analysis of Scheme 1 were used to synthesize compound 16 (Fig. 1, compound $\mathbf{B}$ ) and to access additional heterocyclic intermediates for bioactivity testing.

The synthetic sequence commenced with the commercially available propiophenone $\mathbf{1 2}$ (Scheme 5) which was sequentially

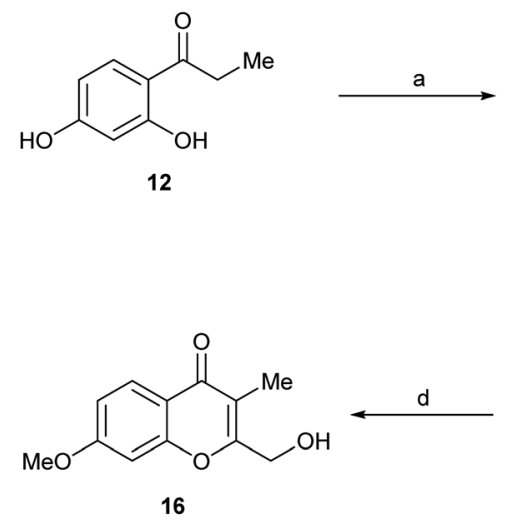<smiles>[R6]Oc1ccc2c(=O)c(C)c(C)oc2c1</smiles>

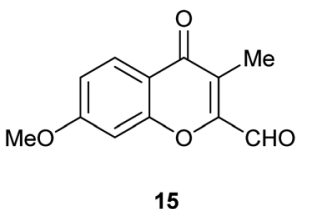

Scheme 5 Reagents and conditions: (a) $1 . \mathrm{Ac}_{2} \mathrm{O}, \mathrm{NaOAc}$, reflux, $3 \mathrm{~h} ; 2$. $\mathrm{Et}_{3} \mathrm{~N}, 115^{\circ} \mathrm{C}, 14 \mathrm{~h} ; 3.1 \mathrm{M} \mathrm{HCl}, 40{ }^{\circ} \mathrm{C}, 6 \mathrm{~h}$ (77\% overall); (b) $\mathrm{Mel}, \mathrm{K}_{2} \mathrm{CO}_{3}$, $\mathrm{Me}_{2} \mathrm{CO}$, reflux, $24 \mathrm{~h}(93 \%) ;(\mathrm{c}) \mathrm{I}_{2}, \mathrm{TsOH}, \mathrm{DMSO}, \mathrm{O}_{2}, 130{ }^{\circ} \mathrm{C}, 2 \mathrm{~h}(78 \%) ;(\mathrm{d})$ $\mathrm{NaBH}_{4}, \mathrm{EtOH}, \mathrm{O}^{\circ} \mathrm{C} \rightarrow \mathrm{RT}, 1 \mathrm{~h}(71 \%)$. 
exposed to $\mathrm{Ac}_{2} \mathrm{O} / \mathrm{NaOAc},{ }^{20} \mathrm{Et}_{3} \mathrm{~N}$ and $\mathrm{HCl}$. Under these conditions, it experienced an exhaustive acetylation, followed by a Baker-Venkataraman rearrangement and cyclization, and a final dehydration and deacetylation to afford 13 in $77 \%$ overall yield.

The phenol was methylated under conventional conditions, with $\mathrm{MeI}$ in refluxing acetone, using $\mathrm{K}_{2} \mathrm{CO}_{3}$ as base to afford 14 (93\%). This is a natural product, which has been recently isolated from Rhinocladiella sp. ${ }^{4 b}$ and from the co-culture of a marine-derived Actinomycete (Streptomyces rochei MB037) and the fungus Rhinocladiella similis 35. Compound 14 proved to display weak antibacterial activity against Staphylococcus aureus and Pseudomonas aeruginosa. ${ }^{21}$

Next, 14 was selectively oxidized with the DMSO-I $\mathrm{I}_{2}$ reagent system, providing aldehyde 15 in $78 \%$ yield. ${ }^{22}$ Finally, the aldehyde was selectively reduced with the aid of the $\mathrm{NaBH}_{4}$, affording the alcohol 16 (Fig. 1, compound B) in 71\% yield. This synthetic route provided the natural product 16 with an overall yield of $39.7 \%$ in just four steps.

\subsection{Evaluation of bioactivity}

The methods employed are fully described in the ESI. $\dagger$ Initially, antifungal susceptibility tests were carried out, with the determination of the minimum inhibitory concentration (MIC) and the minimum fungicidal concentration (MFC). The antifungal activity of the compounds was assessed in the concentration range $0.49-250 \mu \mathrm{g} \mathrm{mL}^{-1}$ with the standardized CLSI microbroth dilution method for yeasts ${ }^{23}$ against C. albicans ATCC 10231. Initially, the aldehyde $\mathbf{1 0}$ and the natural product (1) were screened; however, in order to obtain a better insight into the structural factors implied in the bioactivity, their precursors 2 and 9 as well as the related 7-substituted 2,3-dimethylchromones 13 and 14 were also tested, along with the aldehyde $\mathbf{1 5}$ and the natural product $\mathbf{1 6 .}$

The results are collected in Fig. 2, which depicts the percentage of growth inhibition of a standardized inoculum of

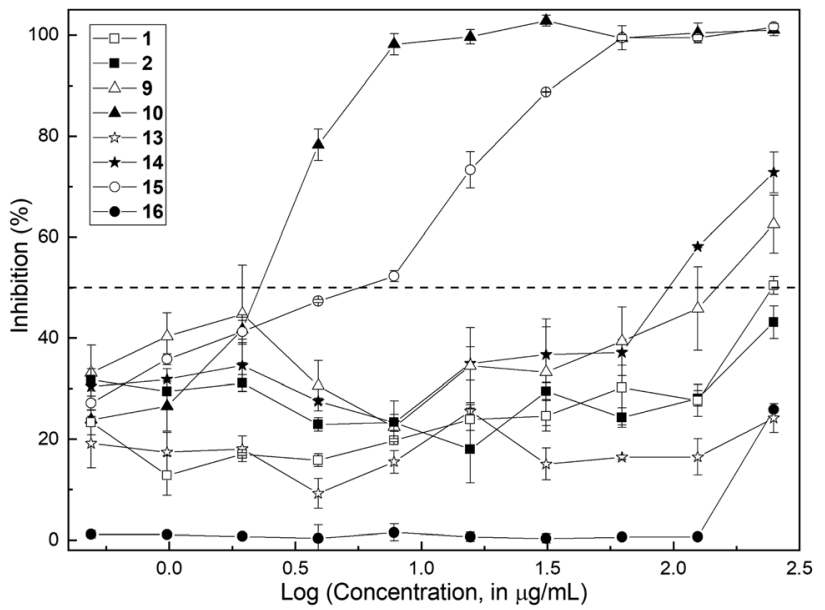

Fig. 2 Semi-logarithmic plot of the growth inhibition of Candida albicans ATCC 10231 in the presence of different concentrations of the chromone test compounds. The dashed line indicates the $50 \%$ inhibition level.
C. albicans $\left(1 \times 10^{3} \mathrm{CFU}\right.$ per $\left.\mathrm{mL}\right)$ plotted against the logarithm of the corresponding concentration of each compound.

The assay revealed that the natural product (1) is a very weak inhibitor, being considered inactive. It barely caused 50\% inhibition at a concentration of $250 \mu \mathrm{g} \mathrm{mL} \mathrm{mL}^{-1}(\mathrm{MIC}>250 \mu \mathrm{g}$ $\left.\mathrm{mL}^{-1}\right)$; quite a similar profile was exhibited by its phenolic precursor 9 (63\% inhibition at $\left.250 \mu \mathrm{g} \mathrm{mL}^{-1}\right)$. On the contrary, the aldehyde $\mathbf{1 0}$ proved to be a very good inhibitor with $\mathrm{MIC}=$ $7.8 \mu \mathrm{g} \mathrm{mL} \mathrm{m}^{-1}$.

Regarding the 7-substituted chromones, compounds 13, 14 and 16 demonstrated to be inactive. Compound 14 exhibited $72.8 \%$ inhibition at $250 \mu \mathrm{g} \mathrm{mL}^{-1}$ (MIC > $250 \mu \mathrm{g} \mathrm{mL}^{-1}$ ), whereas aldehyde 15 was moderately active, with a MIC value of $62.5 \mu \mathrm{g}$ $\mathrm{mL}^{-1}$. The MFC values for the isomeric active aldehydes 10 and 15 were also determined according to the established protocol, ${ }^{23}$ being $125 \mu \mathrm{g} \mathrm{mL}{ }^{-1}$ in both cases.

The results suggested that the presence of a formyl moiety is relevant for the observed activity, and that the latter can be modulated by the position of the oxygenated substituent in the homocyclic ring.

Next, the effect of the heterocycles on the virulence factors of C. albicans were examined. The tests included inhibition of the adherence to buccal epithelial cells, inhibition of the formation of the germ-tube, morphogenesis of $C$. albicans on solid media and the inhibition of lytic enzymes.

The first step by which a microorganism can initiate an infection is through adherence to an epithelial surface; this ability enables it to exist in biofilms and is in clear association with its virulence. ${ }^{24}$ In order to evaluate whether the active compounds are able to affect this process, at sub-lethal concentrations, compounds $\mathbf{1 0}$ and $\mathbf{1 5}$ were submitted to the assay of inhibition of the adherence to buccal epithelial cells (BEC).

The results (Fig. 3A) showed that the number of yeasts adhered to 100 BEC decreased from $2972 \pm 233$ in the untreated control cells to $177 \pm 60$, in the presence of compound $\mathbf{1 0}$ at MFC/2; interestingly, the compound was still active at MFC/32 (number of yeasts adhered to 100 BEC $=1724 \pm 399$ ). Further, as seen in Fig. 3B, treatment with sub-lethal concentrations of compound $\mathbf{1 5}$ also caused a remarkable decrease in yeast adherence to BEC at levels ranging from MFC/2 (482 \pm $187)$ to $\mathrm{MFC} / 8(1334 \pm 233)$.
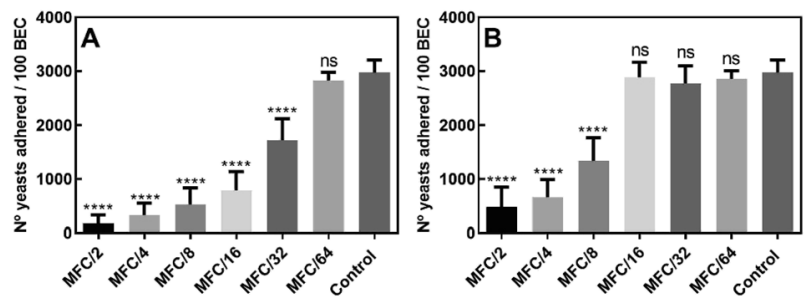

Fig. 3 Adherence of Candida albicans ATCC 10231 to human buccal epithelial cells (BEC) after incubation in media containing sub-lethal concentrations of $10(A)$ and $15(B)$. The adherence to $B E C$ is expressed as the number of adhered yeasts/100 BEC. Wilcoxon test $=* * * *(p<$ 0.0001), ns: not significant. 
These results clearly indicated that the amount of adhered fungal cells to BEC was significantly lower (Wilcoxon test, $p<$ 0.0001) in yeasts treated with both aldehydes than in the untreated cells, suggesting that the presence of these heterocycles causes some degree of resistance to the colonization of BEC by $C$. albicans.

In the germ-tube inhibition assay, the effect of different geometrically distributed sub-lethal concentrations (MFC/64MFC/2) of compounds $\mathbf{1 0}$ and $\mathbf{1 5}$ on the formation of germ tubes (GT) in C. albicans was assessed.

The results (Fig. 4A) showed that the presence of compound 10 at concentrations between MFC/2 and MFC/32, inhibited the formation of hyphae $(\mathrm{GT} \%=48.5 \pm 2.1 \%$ at $\mathrm{MFC} / 32)$ in a dosedependent way with respect to the control (GT\% $=92 \pm 1.4 \%)$. The maximum degree of inhibition was recorded at MFC/2 $(\mathrm{GT} \%=12.0 \pm 1.4 \%)$.

Compound 15 proved to be a less powerful inhibitor (Fig. 4B), which inhibited hyphae formation up to a concentration of $\mathrm{MFC} / 8(\mathrm{GT} \%=59 \pm 1.4 \%)$. At MFC/2, the observed GT\% was $16.0 \pm 1.4 \%$. The results were all statistically significant according to the Holm-Sidak test $(p<0.05)$.

The morphogenesis of $C$. albicans on solid media was studied by examining the effects of compounds $\mathbf{1 0}$ and $\mathbf{1 5}$ on the formation of pseudomycelium in C. albicans in the nutrientpoor Spider medium, that induces pseudohyphal morphogenesis. It was observed that the aldehyde $\mathbf{1 0}$ effectively reduced formation of the hyphal pseudomycelium up to a concentration of MFC/4. This effect was apparent by the smoother aspect of the colonies and the notable reduction of hyphae at the edges. On the other hand, in the presence of compound 15, the $C$. albicans colonies showed their typical filamentation at the edges, suggesting that this heterocycle is not an effective inhibitor of pseudomycelium formation.

Finally, in the study of lytic enzyme inhibition, it was detected a statistically significant inhibition of phospholipases secretion in the presence of compound 10 at $\mathrm{MFC} / 2(\mathrm{Pz}=0.92 \pm$ $0.01)$ and $\mathrm{MFC} / 4(\mathrm{Pz}=0.82 \pm 0.02)$ with respect to the control $(\mathrm{Pz}=0.74 \pm 0.02)$. Contrarily, however, no significant changes in the $\mathrm{Pz}$ index were observed between the untreated (control) cells and those exposed to compound 15. This signaled that the secretion of phospholipases was not inhibited.

On the other hand, it was also observed that at sub-lethal concentrations, compounds $\mathbf{1 0}$ and $\mathbf{1 5}$ did not inhibit
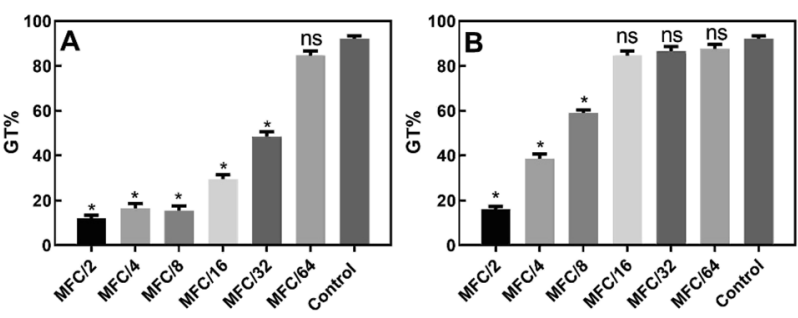

Fig. 4 Candida albicans ATCC 10231 germ tube formation (\% cells) either without (control) or with exposure to sub-lethal concentrations of compounds $10(\mathrm{~A})$ and 15 (B). Holm-Sidak test $=*(p<0.05)$, ns: not significant. secretion of $C$. albicans esterases, since their values of the $\mathrm{Pz}$ index $(\mathrm{Pz}=0.82 \pm 0.02)$ were the same as the control.

In view of these promising observations, the interaction of the chromone derivatives on formation of the C. albicans biofilm and on preformed biofilms was examined. In the first case, an inoculum prepared according to Pierce et al. was used, employing yeast extract-peptone-dextrose (YPD) medium. ${ }^{25}$

Fig. 5A displays the data related to the inhibition of the formation of the $C$. albicans biofilm in the presence of different concentrations of compounds $\mathbf{1 0}$ and 15. A compound was considered active if it significantly inhibited biofilm formation at concentrations below the MIC (sub-inhibitory). However, it was detected that none of the heterocycles managed to completely avoid formation of the biofilm.

In the presence of 10 at a level of $250 \mu \mathrm{g} \mathrm{mL} \mathrm{m}^{-1}$, the inhibition was $67.6 \%\left(54.5 \%\right.$ at $\left.125 \mu \mathrm{g} \mathrm{mL} \mathrm{m}^{-1}\right)$, while 15 exhibited meager values of $45.6 \%$ and $23.7 \%$ inhibition at the same concentrations, respectively. Not unexpectedly, at the corresponding MIC values, their degree of inhibition lacked statistical significance; therefore, based on these results, none of the heterocycles inhibited biofilm formation.

On the other hand, when the antifungal activity against preformed $C$. albicans biofilms was evaluated, it was observed that compounds 10 and 15 displayed almost complete inhibition at concentrations of 62.5 and $250 \mu \mathrm{g} \mathrm{mL}{ }^{-1}$, respectively. Further, compound $\mathbf{1 0}$ caused over $60 \%$ inhibition when the concentration was halved. The effect was concentration dependent, as reflected in the progressive increase in cell viability with reducing concentrations of both compounds.

The results indicate that, while the MIC of compound $\mathbf{1 0}$ against planktonic cells of C. albicans is $7.8 \mu \mathrm{g} \mathrm{mL} \mathrm{m}^{-1}$, the aldehyde can completely inhibit the growth of the biofilm yeast colonies at a concentration of $62.5 \mu \mathrm{g} \mathrm{mL}{ }^{-1}$, suggesting that it may be a useful and promising advantage in the development of more effective anti-biofilm agents.
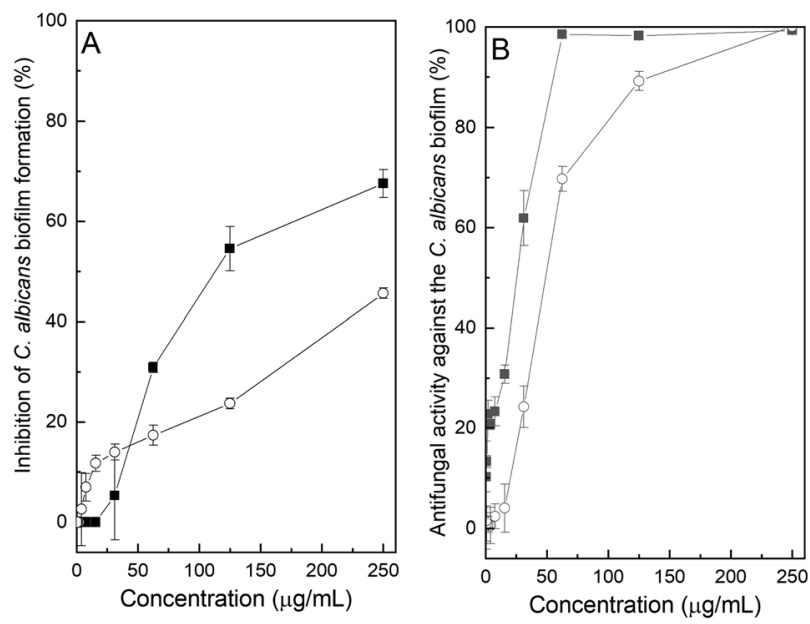

Fig. 5 Activity of compounds $10(\boldsymbol{\square})$ and $15(O)$ against the C. albicans ATCC 10231 biofilm. (A) Inhibition of the biofilm formation. (B) Antifungal activity against the pre-formed biofilm. 


\section{Conclusions}

Two facile and expedient approaches to the first total synthesis of chromanone A, a unique chromone isolated from an algicolous fungus Penicillium sp., endophyte of the Egyptian green alga Ulva sp., were developed. In the most efficient sequence, the heterocycle was accessed in only five steps and $25.3 \%$ overall yield from pyrocatechol, a commercial and easily available starting material.

The key stages of the synthesis included a selective FriedelCrafts acylation of the starting catechol under $\mathrm{BF}_{3} \cdot \mathrm{Et}_{2} \mathrm{O}$ promotion and the aerobic oxidation of the C-2 methyl group of a chromone intermediate by the $\mathrm{I}_{2} / \mathrm{DMSO}$ reagent system. To the best of our knowledge, this is the first report of the use of this approach and this reagent system for the synthesis of 2formyl- and 2-hydroxymethyl chromones. A 7-methoxy isomer of the natural product, which is also a fungal natural product, was prepared following the same strategy. Neither of the synthetic sequences required the use of protecting groups, favouring the efficiency of the syntheses.

The tests of antifungal activity against $C$. albicans revealed that 8-methoxy-3-methyl-4-oxo- $4 H$-chromene-2-carbaldehyde, the 2-formyl analogue of chromanone A, exhibited a $\mathrm{MIC}=$ $7.8 \mu \mathrm{g} \mathrm{mL}{ }^{-1}\left(\mathrm{MFC}=125 \mu \mathrm{g} \mathrm{mL}{ }^{-1}\right)$. In addition, at sub-lethal concentration levels, this compound significantly inhibited various $C$. albicans virulence factors, including the secretion of phospholipases and the yeast adherence to buccal epithelial cells, as well as the formation of the hyphal pseudomycelium and germ tubes. On the other hand, the formyl derivative completely inhibited the growth of $C$. albicans in preformed biofilms at $62.5 \mu \mathrm{g} \mathrm{mL} \mathrm{m}^{-1}$.

Taken together, the results indicate that the 2-formyl analogue of chromanone A not only kills C. albicans, but also inhibits its virulence factors, suggesting that it is able to target both, the cell growth and the pathogenic process. These features turn the aldehyde into a potentially useful lead to develop more effective agents to fight this yeast in biofilm scenarios. These findings also support the hypothesis that marine fungi may be important sources of inspiration for the development of new agents to combat biofilm-forming microorganisms, and perhaps help to overcome difficulties or failure of current therapy for fungal infections.

\section{Experimental section}

\subsection{General information}

The chemical transformations were carried out under dry argon atmospheres, employing freshly distilled anhydrous solvents and oven-dried glassware. Anhydrous $\mathrm{CH}_{2} \mathrm{Cl}_{2}$ was obtained from an MBraun solvent purifier and dispenser system. Absolute EtOH was prepared by refluxing the commercial solvent over clean $\mathrm{Mg} / \mathrm{I}_{2}$ and distilling from the resulting magnesium alkoxide. Anhydrous $\mathrm{Et}_{3} \mathrm{~N}$ was prepared by distillation of the commercial product from $\mathrm{CaH}_{2}$. The anhydrous solvents were stored in dry Young ampoules. The rest of the solvents and reagents were used as received.
The reactions were monitored by TLC, employing aluminium supported silica gel $60 \mathrm{GF}_{254}$ plates run in different hexanes:EtOAc mixtures. The chromatographic spots were revealed by exposure to UV light (254 and $365 \mathrm{~nm}$ ), followed by spraying with the ethanolic $p$-anisaldehyde/sulfuric acid reagent and gentle heating to improve selectivity.

The flash column chromatographies were developed under positive pressure with slurry-packed silica gel $60 \mathrm{H}$ for thin layer chromatography (particle size $<55 \mu \mathrm{m}$ ), employing gradient of solvent polarity techniques with hexanes:EtOAc.

\subsection{Equipment}

The melting points were determined on an Ernst Leitz Wetzlar model 350 hot-stage microscope and are informed uncorrected. The FT-IR spectra were acquired on a Shimadzu Prestige 21 spectrophotometer, as thin films held between two $\mathrm{NaCl}$ disks or as solid dispersions in $\mathrm{KBr}$ (solid samples). The NMR spectra were recorded in $\mathrm{CDCl}_{3}$ with a Bruker Avance 300 NMR spectrometer (300.13 $\mathrm{MHz}$ for ${ }^{1} \mathrm{H}$ and $75.48 \mathrm{MHz}$ for ${ }^{13} \mathrm{C}$ ). The chemical shifts are reported in the $\delta$ scale, in ppm downfield from TMS $(\delta=0.0 \mathrm{ppm})$. The residual solvent peaks of $\mathrm{CDCl}_{3}\left(\delta_{\mathrm{H}}=7.26 \mathrm{ppm}, \delta_{\mathrm{C}}=77.16 \mathrm{ppm}\right)$, were used as internal references. The scalar coupling constant $(J)$ and width and half-height $\left(w_{1 / 2}\right)$ values are given in Hertz. NOE and $2 \mathrm{D}$ NMR experiments (HSQC and HMBC) were also acquired in order to ensure unambiguous signal assignment. The HRMS were obtained with a Bruker MicroTOF-Q II instrument from UMyMFOR (Buenos Aires, Argentina). The microwave-assisted reactions were carried out in a CEM Discover microwave reactor. The light microscopy observations and determinations were performed with an Eclipse E100 (Nikon Corp., Tokyo, Japan) instrument. The microplates were read in a VERSA Max microplate reader (Molecular Devices, Sunnyvale, CA, USA).

\subsection{2-(1-Hydroxypropyl)-6-methoxyphenol (7)}

A stirred solution of ortho-vanillin $(5,1500 \mathrm{mg}, 9.86 \mathrm{mmol})$ in anhydrous $\mathrm{Et}_{2} \mathrm{O}(10 \mathrm{~mL})$ was purged with nitrogen, cooled to $0{ }^{\circ} \mathrm{C}$ in an ice bath and treated dropwise with a solution of EtMgI $(2.5 \mathrm{M}, 24.6 \mathrm{mmol})$ in $\mathrm{Et}_{2} \mathrm{O}$, prepared in situ from ethyl iodide and magnesium turnings. The mixture was allowed to warm to room temperature and then additionally stirred for 1 hour. At the end of the reaction (assessed by TLC), a saturated solution of $\mathrm{NH}_{4} \mathrm{Cl}$ was added $(10 \mathrm{~mL})$ and the organic products were extracted with $\mathrm{CH}_{2} \mathrm{Cl}_{2}(3 \times 20 \mathrm{~mL})$. The combined organic extracts were washed with brine $(10 \mathrm{~mL})$, dried over anhydrous $\mathrm{MgSO}_{4}$, and concentrated under reduced pressure. Chromatography of the residue provided 7 (1742 $\mathrm{mg}, 97 \%)$ as a yellowish oil. ${ }^{8 b}$ IR (film, $\left.\tilde{\nu}\right): 3443,2965,1620,1593,1487$ and $1454 \mathrm{~cm}^{-1} .{ }^{1} \mathrm{H}$ NMR (300 MHz, $\left.\mathrm{CDCl}_{3}\right): \delta=6.85-6.75(3 \mathrm{H}, \mathrm{m}, \mathrm{H}-$ $3, \mathrm{H}-4, \mathrm{H}-5), 6.31(1 \mathrm{H}, \mathrm{s}, \mathrm{OH}), 4.79\left(1 \mathrm{H}, \mathrm{q}, J=6.3, \mathrm{H}-1^{\prime}\right), 3.90$ (3H, s, OMe), $2.55(1 \mathrm{H}, \mathrm{d}, J=5.6, \mathrm{OH}) 1.97-1.78\left(2 \mathrm{H}, \mathrm{m}, \mathrm{H}-2^{\prime}\right)$ and $0.96(3 \mathrm{H}, \mathrm{t}, J=7.4, \mathrm{Me}) \cdot{ }^{13} \mathrm{C} \mathrm{NMR}\left(75 \mathrm{MHz}, \mathrm{CDCl}_{3}\right): \delta=$ 146.8 (C-6), 143.1 (C-1), 129.5 (C-2), 119.6 (C-3)*, 119.3 (C-4)*, 109.8 (C-5), 73.4 (C-1'), 56.1 (OMe), 30.1 (C-2') and 10.3 (C-Me). 


\subsection{1-(2-Hydroxy-3-methoxyphenyl)propan-1-one (3)}

A stirred solution of 7 (34 mg, $0.19 \mathrm{mmol})$ in EtOAc $(1 \mathrm{~mL})$ was treated with 2-iodoxybenzoic acid $(78 \mathrm{mg}, 0.28 \mathrm{mmol})$ and the mixture was warmed to $80{ }^{\circ} \mathrm{C}$ for $1 \mathrm{~h}$. Once the reaction was completed (after TLC monitoring), the solvent was removed under reduced pressure and the resulting crude was chromatographed, affording $3(27.4 \mathrm{mg}, 81 \%)$ as a yellowish solid, ${ }^{26} \mathrm{mp}$ : 69-71 ${ }^{\circ} \mathrm{C}$ (Lit.: $\left.72-73{ }^{\circ} \mathrm{C}\right) .{ }^{10}$ IR (KBr, $\left.\tilde{\nu}\right): 3420,2918,1636,1458$, 1435, 1368, 1317, 1273, 1252, 1227, 1088, 1022, 986, 822, 806, $770,739,719$ and $625 \mathrm{~cm}^{-1} .{ }^{1} \mathrm{H}$ NMR $\left(300 \mathrm{MHz} \mathrm{CDCl}_{3}\right): \delta=7.37$ $\left(1 \mathrm{H}, \mathrm{dd}, J=1.5,8.0, \mathrm{H}^{-} 6^{\prime}\right), 7.05\left(1 \mathrm{H}, \mathrm{d}, J=8.0, \mathrm{H}-4^{\prime}\right), 6.84(1 \mathrm{H}, \mathrm{t}, J$ $\left.=8.0, \mathrm{H}^{-} 5^{\prime}\right), 3.91(3 \mathrm{H}, \mathrm{s}, \mathrm{OMe}), 3.05(2 \mathrm{H}, \mathrm{q}, J=7.4, \mathrm{H}-2)$ and 1.24 $(3 \mathrm{H}, \mathrm{t}, J=7.4, \mathrm{Me}) .{ }^{13} \mathrm{C} \mathrm{NMR}\left(75 \mathrm{MHz}, \mathrm{CDCl}_{3}\right): \delta=207.5(\mathrm{C}-1)$, $152.8\left(\mathrm{C}-2^{\prime}\right), 149.0\left(\mathrm{C}-3^{\prime}\right), 121.0\left(6^{\prime}\right), 119.3\left(\mathrm{C}^{\prime} 4^{\prime}\right), 118.2\left(\mathrm{C}-5^{\prime}\right)$, $116.7\left(\mathrm{C}-1^{\prime}\right), 56.2$ (OMe), 31.9 (C-2) and $8.2(\mathrm{Me})$. HRMS (ESI $\left.{ }^{+}\right)$ calcd for $\mathrm{C}_{10} \mathrm{H}_{13} \mathrm{O}_{3}\left[\mathrm{M}^{+}\right]$: 181.0859, found 181.0859.

\subsection{Ethyl 8-methoxy-3-methyl-4-oxo-4H-chromene-2- carboxylate (8)}

Under an argon atmosphere, anhydrous triethylamine (198 mg, $1.95 \mathrm{mmol}$ ) and ethyl chlorooxoacetate ( $67 \mathrm{mg}, 0.49 \mathrm{mmol}$ ) were successively added to a stirred solution of 3 (44 $\mathrm{mg}, 0.24 \mathrm{mmol}$ ) in anhydrous $\mathrm{CH}_{2} \mathrm{Cl}_{2}(1 \mathrm{~mL})$, placed in a microwave vial. The mixture was heated at $100{ }^{\circ} \mathrm{C}$ in a microwave oven for $1 \mathrm{~h}$; after its completion was confirmed by TLC, it was cooled to room temperature and diluted with brine $(10 \mathrm{~mL})$. The reaction products were extracted with EtOAc $(3 \times 20 \mathrm{~mL})$. The combined organic extracts were washed with brine $(5 \mathrm{~mL})$, dried over $\mathrm{MgSO}_{4}$ and concentrated under reduced pressure. The resulting residue was subjected to chromatography, giving 8 (26 mg, 42\%) as a yellowish oil. ${ }^{1} \mathrm{H} \mathrm{NMR}\left(300 \mathrm{MHz}, \mathrm{CDCl}_{3}\right): \delta=7.75(1 \mathrm{H}, \mathrm{dd}, J$ $=1.5,8.0, \mathrm{H}-5), 7.32(1 \mathrm{H}, \mathrm{t}, J=8.0, \mathrm{H}-6), 7.18(1 \mathrm{H}, \mathrm{dd}, J=1.5$, 8.0, H-7), 4.49 (2H, q, $\left.J=7.2, \mathrm{CH}_{2} \mathrm{Me}\right), 4.01$ (3H, s, OMe), 2.37 $(3 \mathrm{H}, \mathrm{s}, \mathrm{Me})$ and $1.46\left(3 \mathrm{H}, \mathrm{t}, J=7.2, \mathrm{CH}_{2} \mathrm{Me}\right) .{ }^{13} \mathrm{C} \mathrm{NMR}(75 \mathrm{MHz}$, $\mathrm{CDCl}_{3}$ ): $\delta=178.8$ (C-4), $161.8\left(\mathrm{CO}_{2} \mathrm{Et}\right), 148.9$ (C-2), 148.7 (C-8), 146.0 (C-8a), 125.1 (C-6), 123.9(C-3), 123.5 (C-4a), 116.7 (C-5), 114.7 (C-7), $62.6\left(\mathrm{CH}_{2} \mathrm{Me}\right), 56.5(\mathrm{OMe}), 14.1\left(\mathrm{CH}_{2} \mathrm{Me}\right)$ and 10.3 (Me-3). HRMS (ESI ${ }^{+}$) calcd for $\mathrm{C}_{14} \mathrm{H}_{15} \mathrm{O}_{5}\left[\mathrm{M}^{+}\right]$: 263.0914, found 263.0911.

\subsection{2-(Hydroxymethyl)-8-methoxy-3-methyl-4H-chromen-4-} one (1)

A cold $\left(5{ }^{\circ} \mathrm{C}\right)$ mixture of $\mathrm{CaCl}_{2}(13.0 \mathrm{mg}, 0.11 \mathrm{mmol})$ and $\mathrm{NaBH}_{4}$ $(3.5 \mathrm{mg}, 0.09 \mathrm{mmol})$ in an EtOH : THF $(1: 1 \mathrm{v} / \mathrm{v}, 500 \mu \mathrm{L})$ solvent mixture was added to a stirred solution of $8(20 \mathrm{mg}, 0.08 \mathrm{mmol})$ in EtOH : THF $(1: 1 \mathrm{v} / \mathrm{v}, 500 \mu \mathrm{L})$, placed in an ice-water bath. After $24 \mathrm{~h}$, no starting material was observed by TLC and the reaction was quenched with acetone $(1 \mathrm{~mL})$, the solvents were removed under reduced pressure and the crude product was chromatographed, yielding $1(6.8 \mathrm{mg}, 41 \%)$ as a yellow solid, mp: $152-154{ }^{\circ} \mathrm{C}$. IR (KBr, $\left.\tilde{\nu}\right): 3397,2955,2916,2849,1734,1717$, 1684, 1636, 1609, 1570, 1497, 1458, 1398, 1375, 1362, 1285, $1265,1225,1179,1163,1115,1072$ and $1020 \mathrm{~cm}^{-1} \cdot{ }^{1} \mathrm{H}$ NMR $(300$ $\left.\mathrm{MHz} \mathrm{CDCl}_{3}\right): \delta=7.76(1 \mathrm{H}, \mathrm{dd}, J=1.4,8.0, \mathrm{H}-5), 7.29(1 \mathrm{H}, \mathrm{t}, J=$ 8.0, H-6), 7.12 (1H, dd, $J=1.4,8.0, \mathrm{H}-7), 4.75$ (2H, s, H-1'), 3.98
(3H, s, OMe), $2.65\left(1 \mathrm{H}, \mathrm{bs}, w_{1 / 2}=13, \mathrm{OH}\right)$, and $2.12(3 \mathrm{H}, \mathrm{s}, \mathrm{Me}-3)$. ${ }^{13} \mathrm{C} \mathrm{NMR}\left(75 \mathrm{MHz}, \mathrm{CDCl}_{3}\right.$ ): $\delta=178.3(\mathrm{C}-4), 160.5$ (C-2), 148.5 (C8), 146.2 (C-8a), 124.5 (C-6), 123.6 (C-4a), 117.4 (C-3), 116.8 (C-5), $113.8(\mathrm{C}-7), 60.4\left(\mathrm{CH}_{2}\right), 56.2(\mathrm{OMe})$ and $9.2(\mathrm{Me}-3)$.

${ }^{1} \mathrm{H}$ NMR $\left(300 \mathrm{MHz}, \mathrm{MeOH}-d_{4}\right): \delta=8.00(1 \mathrm{H}, \mathrm{dd}, J=1.5,7.8$, $\mathrm{H}-5), 7.03$ (1H, bs, H-6), 7.02 (1H, dd, $J=1.5,7.8, \mathrm{H}-7), 4.62$ $\left(2 \mathrm{H}, \mathrm{s}, \mathrm{H}-1^{\prime}\right), 3.98$ (3H, s, OMe) and 2.07 (3H, s, Me). ${ }^{13} \mathrm{C}$ NMR (75 $\left.\mathrm{MHz}, \mathrm{MeOH}-d_{4}\right): \delta=180.1(\mathrm{C}-4), 166.0$ (C-8a), 164.2 (C-8), 159.4 (C-2), 127.7 (C-6), 118.1 (C-4), 117.3 (C-4a), 116.0 (C-7), 101.0 (C3), $60.7\left(\mathrm{CH}_{2}\right), 56.5(\mathrm{OMe})$ and $9.2(\mathrm{Me}-3)$. The NMR signals of the synthetic compound in $\mathrm{MeOH}-d_{4}$ were in agreement with those of the natural product (compound A). ${ }^{3}$

\subsection{1-(2,3-Dihydroxyphenyl)propan-1-one (4)}

A mixture of pyrocatechol (6, $100 \mathrm{mg}, 0.91 \mathrm{mmol}), \mathrm{BF}_{3} \mathrm{OEt}$ (128.9 $\mathrm{mg}, 0.91 \mathrm{mmol}$ ) and propionic acid (807 $\mathrm{mg}, 10.9 \mathrm{mmol}$ ) reacted together under microwave irradiation at $160{ }^{\circ} \mathrm{C}$, without any solvent for a short time. After cooling to room temperature, the reaction mixture was dissolved in dichloromethane $(10 \mathrm{~mL})$ and brine (about $20 \mathrm{~mL}$ ). After extraction of the organic phase, it was washed with aqueous $\mathrm{NaHCO}_{3}(20 \mathrm{~mL})$, dried with $\mathrm{MgSO}_{4}$, filtered and evaporated to give a crude product. The crude product was chromatographed to afford 11 (92 mg, 61\%), as a yellow solid, mp: $54-56{ }^{\circ} \mathrm{C}$ (Lit.: $\left.56-57^{\circ} \mathrm{C}\right) .{ }^{16 a} \mathrm{IR}(\mathrm{KBr}, \tilde{\nu}): 3566$, 3491, 2978, 2940, 1643, 1636, 1597, 1456, 1452, 1369, 1271, 1109, 1076, 1045, 880, 820 and $731 \mathrm{~cm}^{-1} .{ }^{1} \mathrm{H}$ NMR (300 $\mathrm{MHz}, \mathrm{CDCl}_{3}$ ): $\delta=7.31\left(1 \mathrm{H}, \mathrm{dd}, J=1.4,8.2, \mathrm{H}-6^{\prime}\right), 7.12\left(1 \mathrm{H}, \mathrm{dd}, J=1.4,7.9, \mathrm{H}-4^{\prime}\right)$, $6.81\left(1 \mathrm{H}, \mathrm{t}, J=8.0, \mathrm{H}-5^{\prime}\right), 5.75\left(2 \mathrm{H}, \mathrm{bs}, w_{1 / 2}=76,2 \times \mathrm{OH}\right) .3 .04$ $\left(2 \mathrm{H}, \mathrm{q}, J=7.3, \mathrm{CH}_{2}\right)$ and $1.24(3 \mathrm{H}, \mathrm{t}, J=7.3, \mathrm{Me}) .{ }^{13} \mathrm{C} \mathrm{NMR}(75$ $\left.\mathrm{MHz}, \mathrm{CDCl}_{3}\right): \delta=207.7$ (C-1), $149.5\left(\mathrm{C}-2^{\prime}\right), 145.5\left(\mathrm{C}-3^{\prime}\right), 120.5$ (C$\left.\left.6^{\prime}\right), 120.0\left(\mathrm{C}-4^{\prime}\right), 119.1\left(\mathrm{C}-1^{\prime}\right), 118.9\left(\mathrm{C}^{\prime}\right)^{\prime}\right), 31.7\left(\mathrm{CH}_{2}\right)$ and $8.2(\mathrm{Me})$.

\subsection{8-Hydroxy-2,3-dimethyl-4H-chromen-4-one (9)}

A solution of $4(110 \mathrm{mg}, 0.66 \mathrm{mmol})$ in $\mathrm{Ac}_{2} \mathrm{O}(2973 \mathrm{mg}, 29.13$ $\mathrm{mmol})$ was treated with anhydrous $\mathrm{NaOAc}(271 \mathrm{mg}, 3.31 \mathrm{mmol})$ and the mixture was heated under reflux for $3 \mathrm{~h}$. The excess $\mathrm{Ac}_{2} \mathrm{O}$ was distilled under reduced pressure $(6 \mathrm{~mm} \mathrm{Hg})$, the residue was suspended with AcOEt and the remainder of NaOAc was filtered off under reduced pressure, supplying a mixture of acetates. The acetates were treated with anhydrous $\mathrm{Et}_{3} \mathrm{~N}(0.5 \mathrm{~mL})$ and the mixture was heated for $14 \mathrm{~h}$ at $115{ }^{\circ} \mathrm{C}$. After that period, the reaction was cooled to room temperature, the solvent was removed under reduced pressure and the residue was treated with $1 \mathrm{M} \mathrm{HCl}$ solution at $5{ }^{\circ} \mathrm{C}(5 \mathrm{~mL})$. The resulting suspension was stirred for $6 \mathrm{~h}$ at $40^{\circ} \mathrm{C}$ and the white precipitate formed was filtered under reduced pressure and washed with water at $5{ }^{\circ} \mathrm{C}$. Chromatography of the product provided 9 (96.1 $\mathrm{mg}, 76 \%$ overall), as a yellowish solid, mp: $195-197{ }^{\circ} \mathrm{C}$ (Lit.: $\left.203-204{ }^{\circ} \mathrm{C}\right) .{ }^{27} \mathrm{IR}$ (KBr, $\tilde{\nu}): 3462$, 3447, 3416, 1636, 1616, 1578, 1558, 1362, 1269, 1159, 1134, 762 and $619 \mathrm{~cm}^{-1} .{ }^{1} \mathrm{H}$ NMR $\left(300 \mathrm{MHz},\left(\mathrm{CD}_{3}\right)_{2} \mathrm{CO}\right): \delta=$ 9.05 (1H, s, OH), 7.59-7.51 (1H, m H-5), 7.26-7.19 (2H, m, H-6, H7), $2.45(3 \mathrm{H}, \mathrm{s}, \mathrm{Me}-3)$ and $2.00(3 \mathrm{H}, \mathrm{s}, \mathrm{Me}-2) .{ }^{13} \mathrm{C} \mathrm{NMR}(75 \mathrm{MHz}$, $\left.\left(\mathrm{CD}_{3}\right)_{2} \mathrm{CO}_{3}\right): \delta=177.5(\mathrm{C}-4), 162.3(\mathrm{C}-2), 147.0(\mathrm{C}-8), 146.2(\mathrm{C}-8 \mathrm{a})$, 125.2 (C-6), 124.5 (C-4a), 118.9 (C-7), 117.1 (C-3), 116.1 (C-5), 18.3 (Me-2) and 10.0 (Me-3). HRMS (ESI ${ }^{+}$) calcd for $\mathrm{C}_{11} \mathrm{H}_{11} \mathrm{O}_{3}\left[\mathrm{M}^{+}\right]$: 191.0703, found 191.0705. 


\subsection{8-Methoxy-2,3-dimethyl-4H-chromen-4-one (2)}

A solution of 9 (69 $\mathrm{mg}, 0.36 \mathrm{mmol})$ and $\mathrm{K}_{2} \mathrm{CO}_{3}(70,2 \mathrm{mg}, 0.51$ $\mathrm{mmol})$ in anhydrous acetone $(1 \mathrm{~mL})$ was heated under reflux and treated with $\mathrm{MeI}(66.9 \mathrm{mg}, 0.47 \mathrm{mmol})$ for $24 \mathrm{~h}$. Then the solvent was evaporated, brine $(10 \mathrm{~mL})$ added, and the product was extracted with EtOAc $(3 \times 20 \mathrm{~mL})$. The combined extracts were concentrated under reduced pressure and the residue was chromatographed to afford 2 (70 $\mathrm{mg}, 94 \%)$, as a white solid, mp: 149-151 ${ }^{\circ} \mathrm{C}$ (Lit.: $\left.154{ }^{\circ} \mathrm{C}\right) .{ }^{17 c}{ }^{1} \mathrm{H}$ NMR $\left(300 \mathrm{MHz}, \mathrm{CDCl}_{3}\right): \delta=7.72$ $(1 \mathrm{H}, \mathrm{dd}, J=1.4,8.1, \mathrm{H}-5), 7.22(1 \mathrm{H}, \mathrm{t}, J=8.0, \mathrm{H}-6), 7.07$ (1H, dd, $J$ $=1.4,7.9, \mathrm{H}-7), 3.95(3 \mathrm{H}, \mathrm{s}, \mathrm{OMe}), 2.43(3 \mathrm{H}, \mathrm{s}, \mathrm{Me}-3)$ and 2.04 $(3 \mathrm{H}, \mathrm{s}, \mathrm{Me}-2) .{ }^{13} \mathrm{C}$ NMR (75 MHz, $\left.\mathrm{CDCl}_{3}\right): \delta=177.7$ (C-4), 161.6 (C-2), 148.3 (C-8a), 146.3 (C-8), 124.1 (C-6), 123.6 (C-4a), 117.0 (C3), 116.8 (C-5), 113.4 (C-7), 56.2 (OMe), 18.6 (Me-2) and 10.1 (Me3). HRMS (ESI ${ }^{+}$) calcd for $\mathrm{C}_{12} \mathrm{H}_{13} \mathrm{O}_{3}\left[\mathrm{M}^{+}\right]$: 205.0859, found 205.0859.

\subsection{8-Methoxy-3-methyl-4-oxo-4H-chromene-2- carbaldehyde (10)}

A mixture of $2(52.9 \mathrm{mg}, 0.26 \mathrm{mmol}), \mathrm{I}_{2}(13.15 \mathrm{mg}, 0.10 \mathrm{mmol})$, TsOH (44.6 mg, $0.26 \mathrm{mmol}$ ) in DMSO $(1 \mathrm{~mL})$ was heated at $130{ }^{\circ} \mathrm{C}$ under oxygen atmosphere for $2 \mathrm{~h}$. After this time, the reaction solution was washed with saturated $\mathrm{NH}_{4} \mathrm{Cl}(5 \mathrm{~mL})$ and extracted with $\mathrm{CH}_{2} \mathrm{Cl}_{2}(3 \times 5 \mathrm{~mL})$, the organic phase was dried with $\mathrm{MgSO}_{4}$, filtered and the remaining DMSO was distilled under reduced pressure evaporated to give a crude product. The crude product was chromatographed to afford 10 (47 mg, 83\%), as a yellow solid, mp: 150-152 ${ }^{\circ} \mathrm{C}$. IR (KBr, $\left.\tilde{\nu}\right): 3539,3420,3233$, 1724, 1636, 1622, 1605, 1582, 1493, 1458, 1441, 1406, 1377, 1356, 1271, 1227, 1194, 1159, 1121, 1076, 1001, 918, 824 and $752 \mathrm{~cm}^{-1} .{ }^{1} \mathrm{H}$ NMR (300 MHz, $\left.\mathrm{CDCl}_{3}\right): \delta=10.20(1 \mathrm{H}, \mathrm{s}, \mathrm{CHO})$, $7.73(1 \mathrm{H}, \mathrm{dd}, J=1.2,8.4, \mathrm{H}-5), 7.33(1 \mathrm{H}, \mathrm{t}, J=8.1, \mathrm{H}-6), 7.20(1 \mathrm{H}$, $\mathrm{dd}, J=1.4,8.0, \mathrm{H}-7), 4.01$ (3H, s, OMe) and 2.43 (3H, s, Me-2). ${ }^{13} \mathrm{C}$ NMR (75 MHz, $\left.\mathrm{CDCl}_{3}\right): \delta=186.5\left(\mathrm{C}-1^{\prime}\right), 179.2(\mathrm{C}-4), 150.5$ (C-2), 149.1 (C-8), 145.9 (C-8a), 125.3 (C-6, C-3), 123.6 (C-4a), 116.6 (C-5), 114.9 (C-7), 56.4 (OMe) and 8.2 (Me-2). HRMS $\left(\mathrm{ESI}^{+}\right.$) calcd for $\mathrm{C}_{12} \mathrm{H}_{11} \mathrm{O}_{4}\left[\mathrm{M}^{+}\right]$: 219.0652, found 219.0652 .

\subsection{2-(Hydroxymethyl)-8-methoxy-3-methyl-4H-chromen-4- one (1)}

To a solution of $13(24 \mathrm{mg}, 0.11 \mathrm{mmol})$ in EtOH $(1 \mathrm{~mL})$ was added $\mathrm{NaBH}_{4}(5.0 \mathrm{mg}, 0.13 \mathrm{mmol})$ under an argon atmosphere at $0{ }^{\circ} \mathrm{C}$ and stirred the reaction mixture at RT for $1 \mathrm{~h}$. After completion of the reaction, the reaction mixture was quenched with acetone $(1 \mathrm{~mL})$. Then, acetone was distilled under reduced pressure evaporated and the crude product was chromatographed to afford chromanone A $(\mathbf{1}, 17 \mathrm{mg}, 70 \%)$, as a yellow solid. The NMR spectroscopic data of this compound exhibited concordance with those recorded for compound $\mathbf{A}^{3}$ (Fig. 1) and for 1 when obtained from $\mathbf{5}$.

\subsection{7-Hydroxy-2,3-dimethyl-4H-chromen-4-one (13)}

A solution of 2,4-dihydroxypropiophenone (12, $1000 \mathrm{mg}, 6.0$ $\mathrm{mmol})$ in $\mathrm{Ac}_{2} \mathrm{O}(25 \mathrm{~mL}, 265 \mathrm{mmol})$ was treated with anhydrous $\mathrm{NaOAc}$ (2468 mg, $30.1 \mathrm{mmol}$ ) and the mixture was heated under reflux for $3 \mathrm{~h}$. The excess $\mathrm{Ac}_{2} \mathrm{O}$ was distilled under reduced pressure ( $6 \mathrm{~mm} \mathrm{Hg}$ ), the residue was suspended with AcOEt and the remainder of NaOAc was filtered off under reduced pressure, supplying a mixture of acetates. The acetates were treated with anhydrous $\mathrm{Et}_{3} \mathrm{~N}(1 \mathrm{~mL})$ and the mixture was heated for $14 \mathrm{~h}$ at $115{ }^{\circ} \mathrm{C}$. After that period, the reaction was cooled to room temperature, the solvent was removed under reduced pressure and the residue was treated with $1 \mathrm{M} \mathrm{HCl}$ solution at $5{ }^{\circ} \mathrm{C}(40$ $\mathrm{mL}$ ). The resulting suspension was stirred for $6 \mathrm{~h}$ at $40{ }^{\circ} \mathrm{C}$ and the precipitate formed was filtered under reduced pressure and washed with water at $5{ }^{\circ} \mathrm{C}$. Chromatography of the product provided 13 (880 mg, 77\% overall) as a yellowish solid, mp: $280-$ $282{ }^{\circ} \mathrm{C}$ (Lit.: $281{ }^{\circ} \mathrm{C}$ ). ${ }^{28} \mathrm{IR}$ (KBr, $\left.\tilde{\nu}\right): 3993,2924,2853,1653,1558$, 1541, 1458, 1246, 1101, 860 and $689 \mathrm{~cm}^{-1} .{ }^{1} \mathrm{H}$ NMR $(300 \mathrm{MHz}$, acetone- $\left.d_{6}\right): \delta=9.7\left(1 \mathrm{H}, \mathrm{bs}, w_{1 / 2}=42, \mathrm{OH}\right), 7.94(1 \mathrm{H}, \mathrm{d}, J=8.7$, $\mathrm{H}-5), 6.81(1 \mathrm{H}, \mathrm{dd}, J=2.2,8.7, \mathrm{H}-6), 6.71$ (1H, d, $J=2.2, \mathrm{H}-8)$, $2.31(3 \mathrm{H}, \mathrm{d}, J=0.6, \mathrm{Me}-2)$ and $1.96(3 \mathrm{H}, \mathrm{d}, J=0.6, \mathrm{Me}-3) .{ }^{13} \mathrm{C}$ NMR (75 MHz, acetone- $d_{6}$ ): $\delta=177.4(\mathrm{C}-4), 163.2$ (C-7), 162.3 (C2), 158.5 (C-8a), 127.9 (C-5), 116.6 (C-3), 116.4 (C-4a), 115.3 (C-6), 102.7 (C-8), $18.4(\mathrm{Me}-2)$ and $9.9(\mathrm{Me}-3){ }^{7 c}$

\subsection{7-Methoxy-2,3-dimethyl-4H-chromen-4-one (14)}

A solution of 13 (800 mg, $4.21 \mathrm{mmol})$ and $\mathrm{K}_{2} \mathrm{CO}_{3}(813.8 \mathrm{mg}, 5.89$ $\mathrm{mmol})$ in anhydrous acetone $(20 \mathrm{~mL})$ was heated under reflux and treated with MeI (776 mg, $5.47 \mathrm{mmol}$ ) for $24 \mathrm{~h}$. Then the solvent was evaporated, brine added, and the product was extracted with EtOAc. The combined extracts were concentrated under reduced pressure and the residue was chromatographed to afford 14 (795 mg, 93\%) as a as a yellowish solid, ${ }^{21} \mathrm{mp}: 125-$ 127 (Lit.: $\left.127{ }^{\circ} \mathrm{C}\right) .{ }^{29} \mathrm{IR}$ (KBr, $\left.\tilde{\nu}\right): 3420,2924,1636,1605,1443$, 1404, 1352, 1244, 1204, 1111, 1030, 856, 824 and $689 \mathrm{~cm}^{-1} \cdot{ }^{1} \mathrm{H}$ NMR (300 MHz, $\left.\mathrm{CDCl}_{3}\right): \delta=8.09(1 \mathrm{H}, \mathrm{d}, J=8.8, \mathrm{H}-5), 6.92(1 \mathrm{H}$, $\mathrm{dd}, J=2.5,8.8, \mathrm{H}-6), 6.77$ (1H, d, $J=2.5, \mathrm{H}-8), 3.88$ (3H, s, OMe), $2.38(3 \mathrm{H}, \mathrm{d}, J=0.5, \mathrm{Me}-3)$ and $2.04(3 \mathrm{H}, \mathrm{d}, J=0.5, \mathrm{Me}-2) .{ }^{13} \mathrm{C}$ NMR (75 MHz, $\mathrm{CDCl}_{3}$ ): $\delta=177.4$ (C-4), 163.5 (C-7), 161.2 (C-2), 157.6 (C-8a), 127.2 (C-5), 116.6 (C-3), 116.6 (C-4a), 113.9 (C-6), 99.7 (C-8), 55.7 (OMe), 18.4 (Me-2) and 10.0 (Me-3).

\subsection{7-Methoxy-3-methyl-4-oxo-4H-chromene-2- carbaldehyde (15)}

A mixture of 14 (20.4 mg, $0.10 \mathrm{mmol}), \mathrm{I}_{2}(5.07 \mathrm{mg}, 0.04 \mathrm{mmol})$ and $\mathrm{TsOH}$ (17.2 mg, $0.10 \mathrm{mmol}$ ) was heated at $130{ }^{\circ} \mathrm{C}$ under an oxygen atmosphere for $3 \mathrm{~h}$ in DMSO $(1 \mathrm{~mL})$. After this time, the reaction was diluted with saturated $\mathrm{NH}_{4} \mathrm{Cl}$ solution $(10 \mathrm{~mL})$ and the product was extracted with $\mathrm{CH}_{2} \mathrm{Cl}_{2}(3 \times 10 \mathrm{~mL})$. The combined organic phases were dried with $\mathrm{MgSO}_{4}$, and concentrated under reduced pressure. The remaining DMSO was distilled under vacuum and the crude product was chromatographed to afford 15 (17 mg, 78\%) as a yellowish solid, ${ }^{22}$ mp: $118-121{ }^{\circ} \mathrm{C}$. IR (KBr, $\left.\tilde{\nu}\right): 2920,2849,1699,1624,1443,1281$, 1261, 1206, 1159, 1111, 1020, 851, 768 and $623 \mathrm{~cm}^{-1} .{ }^{1} \mathrm{H}$ NMR $\left(300 \mathrm{MHz}, \mathrm{CDCl}_{3}\right): \delta=10.20(1 \mathrm{H}, \mathrm{s}, \mathrm{CHO}), 8.11(1 \mathrm{H}, \mathrm{d}, J=8.9, \mathrm{H}-$ 5), $6.99(1 \mathrm{H}, \mathrm{dd}, J=2.4,8.9, \mathrm{H}-6), 6.93(1 \mathrm{H}, \mathrm{d}, J=2.4, \mathrm{H}-8), 3.92$ (3H, s, OMe) and 2.44 (3H, s, Me-3). $\left.{ }^{13} \mathrm{C} \mathrm{NMR} \mathrm{(75} \mathrm{MHz}, \mathrm{CDCl}_{3}\right)$ : $\delta=185.7\left(\mathrm{C}-1^{\prime}\right), 178.3$ (C-4), 165.1 (C-7), 157.2 (C-8a), 150.6 (C-2), 
127.4 (C-5), 126.6 (C-3), 116.8 (C-4a), 115.7 (C-6), 99.9 (C-8), 55.9 (OMe) and $8.0(\mathrm{Me}-3)$.

4.15 2-(Hydroxymethyl)-7-methoxy-3-methyl-4H-chromen-4one (16)

A stirred solution of $13(10.5 \mathrm{mg}, 0.05 \mathrm{mmol})$ in EtOH $(1 \mathrm{~mL})$ under an argon atmosphere was cooled to $0{ }^{\circ} \mathrm{C}$ and treated with $\mathrm{NaBH}_{4}(2.73 \mathrm{mg}, 0.07 \mathrm{mmol})$. The reaction mixture was further stirred at RT for $1 \mathrm{~h}$, when it was quenched with acetone $(1 \mathrm{~mL})$. The volatiles were removed under reduced pressure and the crude product was chromatographed to afford 13 (7.5 mg, 71\%), as a white solid, mp: $122-125{ }^{\circ} \mathrm{C}$. IR (KBr, $\left.\tilde{\nu}\right): 3323,2924,2853$, 1638, 1597, 1449, 1244, 1177, 1042, 1024 and $827 \mathrm{~cm}^{-1} \cdot{ }^{1} \mathrm{H}$ NMR $\left(300 \mathrm{MHz}, \mathrm{CDCl}_{3}\right): \delta=8.06(1 \mathrm{H}, \mathrm{d}, J=8.9, \mathrm{H}-5), 6.92(1 \mathrm{H}, \mathrm{dd}, J=$ 2.4, 8.9, H-6), 6.74 (1H, d, $J=2.4, \mathrm{H}-8), 4.67\left(2 \mathrm{H}, \mathrm{s}, \mathrm{H}-1^{\prime}\right), 3.87$ (3H, s, OMe), $2.75\left(1 \mathrm{H}, \mathrm{bs}, w_{1 / 2}=16, \mathrm{OH}\right)$ and 2.07 (3H, s, Me-3). ${ }^{13} \mathrm{C} \mathrm{NMR}$ (75 MHz, $\mathrm{CDCl}_{3}$ ): $\delta=178.0$ (C-4), 163.9 (C-7), 160.5 (C2), 157.5 (C-8a), 127.2 (C-5), 117.3 (C-3), 116.4 (C-4a), 114.5 (C-6), 99.6 (C-8), 60.5 (C-1'), 55.7 (OMe) and 9.2 (Me-3). The spectroscopic data of this compound were in full agreement with those recorded for the natural product (compound C). ${ }^{4 b}$

\section{Author contributions}

All the authors were involved in the manuscript, performing conceptualization (IC, TSK, ABJB, LAS), data curation (IC, MAS, LAS), formal analysis (IC, EC, TSK, ABJB), funding acquisition (TSK, ABJB, MAS, LAS), investigation (IC, EC, TSK, ABJB), methodology (IC, EC, TSK, LAS, MAS, ABJB), project administration (TSK, ABJB, LAS, MAS), resources (TSK, ABJB, LAS, MAS), use of software (IC, TSK, ABJB), supervision (ABJB, TSK, MAS, LAS), results validation (TSK), results visualization (IC, EC, TSK), writing - original draft (IC, EC, TSK, ABJB) and writing review \& editing (IC, EC, TSK, LAS, MAS, ABJB).

\section{Conflicts of interest}

There are no conflicts to declare.

\section{Acknowledgements}

The authors gratefully acknowledge Consejo Nacional de Investigaciones Científicas y Técnicas (CONICET, PUE IQUIR 2016) and Agencia Nacional de Promoción Científica y Tecnológica (ANPCyT, PICT 2017-0149 and PICT 2016-1833) for financial support. IC and EC also thank CONICET for their Doctoral fellowships.

\section{References}

1 (a) P. S. Stewart and M. J. Franklin, Nat. Rev. Microbiol., 2008, 6, 199-210; (b) J. W. Costerton, P. S. Stewart and E. P. Greenberg, Science, 1999, 284, 1318-1322.

2 (a) L. Yet, Privileged Structures in Drug Discovery, Wiley, Hoboken, USA, 2018; (b) D. S. Gül, H. Ogutcu and Z. Hayvali, J. Mol. Struct., 2020, 1204, 127569; (c) A. Mendieta-Moctezuma, C. Rugerio-Escalona, N. Villa-
Ruano, R. U. Gutierrez, F. E. Jiménez-Montejo, M. J. Fragoso-Vázquez, J. Correa-Basurto, M. C. Cruz-López, F. Delgado and J. Tamariz, Med. Chem. Res., 2019, 28, 831848.

3 A. M. Gamal-Eldeen, A. Abdel-Lateff and T. Okino, Environ. Toxicol. Pharmacol., 2009, 28, 317-322.

4 (a) T. Tanahashi, Y. Takenaka and N. Hamada, Heterocycles, 2011, 83, 2157-2164; (b) M.-F. Li, G.-H. Li and K.-Q. Zhang, Metabolites, 2019, 9, 58; (c) L.-H. Menga, H.-Q. Chen, I. Form, B. Konuklugil, P. Proksch and B.-G. Wang, Nat. Prod. Commun., 2016, 11, 1293-1296.

5 (a) T. M. L. Do, A. V. Truong, T. N. Vo, T. G. Pinnock, L. M. Pratt, D. Guillaume and K. P. P. Nguyen, Phytochem. Lett., 2013, 6, 544-551; (b) W. Yi-Fen, C. Ji-Jun, Y. Yan, Z. Yong-Tang, T. Shao-Zong and L. Shi-De, Helv. Chim. Acta, 2002, 85, 2342-2348.

6 (a) A. A. Arroyo Aguilar, S. J. Bolívar Avila, T. S. Kaufman and E. L. Larghi, Org. Lett., 2018, 20, 5058-5061; (b) J. L. Pergomet, A. B. J. Bracca and T. S. Kaufman, Org. Biomol. Chem., 2017, 15, 7040-7049; (c) M. V. Méndez, D. A. Heredia, E. L. Larghi, A. B. J. Bracca and T. S. Kaufman, RSC Adv., 2017, 7, 28298-28307; (d) M. V. Méndez, S. O. Simonetti, T. S. Kaufman and A. B. J. Bracca, New J. Chem., 2019, 43, 10803-10813.

7 (a) I. Cortés, C. Borini Etichetti, J. Girardini, T. S. Kaufman and A. B. J. Bracca, Synthesis, 2019, 51, 433-440; (b) J. L. Pergomet, M. G. Di Liberto, M. G. Derita, A. B. J. Bracca and T. S. Kaufman, Fitoterapia, 2018, 125, 98-105; (c) S. O. Simonetti, E. L. Larghi, A. B. J. Bracca and T. S. Kaufman, Org. Biomol. Chem., 2012, 10, 4124-4134.

8 (a) F. Saito, K. Kuramochi, A. Nakazaki, Y. Mizushina, F. Sugawara and S. Kobayashi, Eur. J. Org. Chem., 2006, 4796-4799; (b) W. A. König, H. Faasch, H. Heitsch, C. Colberg and B. M. Hausen, Z. Naturforsch., B: J. Chem. Sci., 1993, 48, 387-393; (c) L. A. Hasvold, L. Hexamer, G. Li, N.-H. Lin, H. Sham, T. Sowin, G. M. Sullivan, L. Wang and P. X. Xia, WO2004/076424A1, 2004; (d) J. Halbrook, E. A. Kesicki, L. E. Burgess, S. T. Schlachter, C. T. Eary, J. G. Schiro, H. Huang, M. Evans and Y. Han, US Pat., US2002/165218A1, 2002.

9 (a) R. Frenette, M. Monette, M. A. Bernstein, R. N. Young and T. R. Verhoeven, J. Org. Chem., 1991, 56, 3083-3089; (b) S. Ducki, R. Forrest, J. A. Hadfield, A. Kendall, N. J. Lawrence, A. T. McGown and D. Rennison, Bioorg. Med. Chem. Lett., 1998, 8, 1051-1056; (c) P. Gogoi, G. K. Sarmah and D. Konwar, J. Org. Chem., 2004, 69, 5153-5154.

10 K. A. Parker and J. J. Petraitis, Tetrahedron Lett., 1981, 22, 397-400.

11 (a) S. Gobbi, Q. Hu, C. Zimmer, M. Engel, F. Belluti, A. Rampa, R. W. Hartmann and A. Bisi, J. Med. Chem., 2016, 59, 2468-2477; (b) M. Kumar, P. Rawat, J. Kureel, A. K. Singh, D. Singh and R. Maurya, Bioorg. Med. Chem. Lett., 2011, 21(2011), 1706-1709.

12 (a) K. S. Lee, S. H. Seo, Y. H. Lee, H. D. Kim, M. H. Son, B. Y. Chung, J. Y. Lee, C. Jin and Y. S. Lee, Bioorg. Med. Chem. Lett., 2005, 15, 2857-2860; (b) S. H. Kim, Y. H. Lee, 
S. Y. Jung, H. J. Kim, C. Jin and Y. S. Lee, Eur. J. Med. Chem., 2011, 46, 1721-1728; (c) F. M. Hauser and W. A. Dorsch, Org. Lett., 2003, 5, 3753-3754.

13 (a) A. M. Helguera, A. Pérez-Garrido, A. Gaspar, J. Reis, F. Cagide, D. Vina, M. N. D. S. Cordeiro and F. Borges, Eur. J. Med. Chem., 2013, 59, 75-90; (b) M. Payard, G. Mouysset, P. Tronche and P. Bastide, Eur. J. Med. Chem., 1985, 20, 117-120; (c) G. E. Daia, C. D. Gabbutt, J. D. Hepworth, B. M. Heron, D. E. Hibbs and M. B. Hursthouse, Tetrahedron Lett., 2002, 43, 4507-4510.

14 (a) J. Bolós, L. Anglada, S. Gubert, J. M. Planas, J. Agut, M. Príncep, A. de la Fuente, A. Sacristán and J. A. Ortiz, J. Med. Chem., 1998, 41, 5402-5409; (b) J. H. Hutchinson and M. W. Rowbottom, WO2017/15221A1, 2017; (c) S. Narasimhan, K. G. Prasad and S. Madhavan, Synth. Commun., 1995, 25, 1689-1697.

15 (a) H. Naeimi and L. Moradi, Bull. Chem. Soc. Jpn., 2005, 78, 284-287; (b) N. Zhang, Z. Yu, X. Yang, Y. Zhou, J. Wang, S.-L. Zhang, M.-W. Wang and Y. He, Eur. J. Med. Chem., 2018, 158, 707-719; (c) K. Wahala and T. A. Hase, J. Chem. Soc., Perkin Trans. 1, 1991, 3005-3008; (d) S.-C. Kuo, K.-H. Lee, L.-J. Huang, L.-C. Chou, T.-S. Wu, T.-D. Way, J.-G. Chung, J.-S. Yang, C.-H. Huang and M.-T. Tsai, US Pat., US2012/15908A1, 2012.

16 (a) M. Albrecht, S. Mirtschin, M. de Groot, I. Janser, J. Runsink, G. Raabe, M. Kogej, C. A. Schalley and R. Fröhlich, J. Am. Chem. Soc., 2005, 127, 10371-10387; (b) A. C. N. Kwamen, J. Jenniches, I. M. Oppel and M. Albrecht, Chem.-Eur. J., 2020, 26, 10550-10554.

17 (a) X. Wang, T. Zhao, B. Yang, Z. Li, J. Cui, Y. Dai, Q. Qiu, H. Qiang, W. Huang and H. Qian, Bioorg. Med. Chem., 2015, 23, 132-140; (b) J. E. Immoos, J. Labelled Compd. Radiopharm., 2015, 58, 419-424; (c) I. M. Helibron,
H. Barnes and R. A. Morton, J. Chem. Soc., Trans., 1923, 123, 2559-2570.

18 (a) R. Ye, Y. Cao, X. Xi, L. Liu and T. Chen, Org. Biomol. Chem., 2019, 17, 4220-4224; (b) M. Raghavender Reddy, N. Nageswara Rao, K. Ramakrishna and H. M. Meshram, Tetrahedron Lett., 2014, 55, 1898-1901; (c) Q. Cai, S. Zhuang, M. Yang, N. Peng, Y. Liu and A. Wu, Tetrahedron, 2019, 75, 130756.

19 R. B. Gammill, J. Org. Chem., 1984, 49, 5035-5041.

20 (a) G. Höfle, B. Kunze, C. Zorzin and H. Reichenbach, Liebigs Ann. Chem., 1984, 1883-1904; (b) N. R. Ayyangar, R. A. Khan and V. H. Deshpande, Tetrahedron Lett., 1988, 29, 2347-2348.

21 M. Yu, Y. Li, S. P. Banakar, L. Liu, C. Shao, Z. Li and C. Wang, Front. Microbiol., 2019, 10, 915.

22 A. Srinivas, Y. Hemasri and R. Y. Jayaprakash, Heterocycl. Lett., 2018, 8, 303-311.

23 Reference method for broth dilution antifungal susceptibility testing of yeasts, 4th edn, approved standard CLSI M27Ed4, Clinical and Laboratory Standard Institute, Wayne, PA, USA, 2017.

24 J. C. O. Sardi, L. Scorzoni, T. Bernardi, A. M. Fusco-Almeida and M. J. S. Mendes Giannini, J. Med. Microbiol., 2013, 62, $10-24$.

25 C. G. Pierce, P. Uppuluri, A. R. Tristan, F. L. Wormley, E. Mowat, G. Ramage and J. L. Lopez-Ribot, Nat. Protoc., 2008, 3, 1494-1500.

26 T. T. Kung, Y. Crawley, B. Luo, S. Young, W. Kreutner and R. W. Chapman, Br. J. Pharmacol., 2000, 130, 457-463.

27 P. Da Re and L. Cimatoribus, Chem. Ber., 1962, 95, 29122920.

28 Y. J. Rao and G. L. D. Krupadanam, Bull. Chem. Soc. Jpn., 1994, 67, 1972-1975.

29 F. W. Canter, F. H. Curd and A. Robertson, J. Chem. Soc. C, 1931, 1255-1265. 